\title{
Evaluation of the lengths and angles of the tips of rotatory files in root canal preparations
}

\author{
Avaliação do comprimento e do ângulo das pontas de \\ instrumentos rotatórios no preparo de canais radiculares
}

\begin{abstract}
Purpose: To detect changes in the angles and lengths of the tips of rotary nickel-titanium files after use.

Methods: Forty human teeth were prepared with eight sets of rotary ProTaper ${ }^{\circledR}$ Universal nickel-titanium files with a length of $25 \mathrm{~mm}$ and rotation of $350 \mathrm{rpm}$. The files were evaluated in a scanning electron microscope (SEM) at three different times: Group A - before use; Group B - after using each file in the preparation of three molars; and Group C - after using each file in the preparation of five molars. The length of the tip was determined by measuring the length of a straight line drawn parallel to the file axis, from the apex of the tip to its posterior border. The SEM software provided the angle measurements. Data were analyzed by using paired t-tests and Wilcoxon tests.

Results: There were no differences between the groups for the S1 file. There was a decrease in length when the F2 file was used to prepare three and five molars, whereas decreases in length were seen when F5 files were used to prepare three or five molars.

Conclusion: The results suggest that the tips of the rotary instruments showed significant changes in length and angle even with relatively low use.
\end{abstract}

Key words: Dental files; Endodontics; molar

\section{Resumo}

Objetivo: Comparar as alterações no ângulo e comprimento da ponta dos alargadores rotatórios após sua utilização em relação à sua configuração original.

Metodologia: Quarenta dentes humanos foram preparados com instrumentos rotatórios de níquel-titânio ProTaper ${ }^{\circledR}$ Universal, $25 \mathrm{~mm}$ e rotação de $350 \mathrm{rpm}$. Os alargadores foram avaliados em um microscópio eletrônico de varredura (SEM) em três grupos: Grupo A - antes do uso dos instrumentos; Grupo B - após o uso de cada instrumento na preparação de três molares; e Grupo C - após o uso de cada instrumento na preparação de cinco molares. $\bigcirc$ comprimento da ponta foi determinado medindo o comprimento de uma linha reta traçado paralelamente ao eixo do instrumento, desde o vértice da ponta até seu limite posterior. $O$ software do SEM forneceu a medição do ângulo delimitado por dois segmentos de retas. Os dados foram analisados estatisticamente por teste t pareado teste de Wilcoxon.

Resultados: Para o instrumento S1 não houve diferença entre os grupos. Para o alargador F2 houve uma diminuição no comprimento entre os grupos $B$ e $C$ e uma diferença entre os grupos A com B e C foi observada no alargador F5.

Conclusão: Os resultados sugerem que a ponta dos instrumentos rotatórios sofreu alterações significativas de comprimento e ângulo com relativo pouco uso.

Palavras chaves: Limas endodônticas; Endodontia; molar

\author{
Mariana Aleluia Drago a \\ Rosana de Souza Pereira ${ }^{a}$ \\ Miguel Ângelo Schettino Junior b
}

\begin{abstract}
- Department of Endodontics, Federal University of Espirito Santo (UFES), Vitória, ES, Brazil

b Department of Physics, Federal University of Espirito Santo (UFES), Vitória, ES, Brazil
\end{abstract}

Correspondence:

Mariana Aleluia Drago

Rua Luis Fernandes Reis, 530/101 - Praia da Costa Vila Velha, ES - Brasil

29101120

E-mail: dragomari@hotmail.com

Received: November 26, 2011

Accepted: January 31, 2012

Conflict of Interests: The authors state that there are no financial and personal conflicts of interest that could have inappropriately influenced their work.

Copyright: (C) 2011 Drago et al.; licensee EDIPUCRS. This is an Open Access article distributed under the terms of the Creative Commons AttributionNoncommercial-No Derivative Works 3.0 Unported License. 


\section{Introduction}

Nickel-titanium alloys have been introduced for the manufacture of endodontic instruments with the aim of replacing the stiffness, i.e., the modulus of elasticity, of stainless steel materials (1-3). These instruments are two to three times more flexible than stainless steel files (4). The alloy used for manufacturing endodontic instruments consists of approximately $55 \%$ nickel and $45 \%$ titanium, and it is generically called 55-Nitinol (5).

Several instrument systems were introduced because of the growing popularity of hand files and nickel titanium rotatory files in endodontic practice, with various features such as design, tip sizing, pitch, cross-sectional helix angle and taper (6,7). In 2006, Dentsply Maillefer introduced the ProTaper ${ }^{\circledR}$ Universal System with modified characteristics of the original ProTaper ${ }^{\circledR}$. The changes included the new rounded tip and removal of the angle of transition to reduce canal transportation and provide greater security. Minor changes were made in the S2 instrument to improve the balance between S1, S2, and F1. The cross-sectional blades of the F2 and F3 instruments were changed to a triangular concave shape with a shallow U-shaped groove at the sides to make them more flexible and homogeneous. The crosssection of the $\mathrm{F} 3$ instrument also became lighter with grooves to reduce the abrasion of the metal section (8-10). New files, F4 and F5, were introduced to accomplish a non-brushing action inside the root canals $(10,11)$.

However, these endodontic instruments may present defects on their surface such as slots, microcavities and a pronounced variation between the actual and nominal dimensions originating in the manufacturing process. Due to this lack of manufacturing precision in the shape and size of these instruments, iatrogenic problems may occur in the final configuration of the endodontic treatment of root canals $(3,10)$. Therefore, standardization has become increasingly important due to demands for safety, quality and uniformity in the production of materials (10). The aim of this study was to detect possible changes in the angle and in the lengths of the tips of the files resulting from their use in preparing root canals.

\section{Material and methods}

The study protocol was approved by the Federal University of Espiríto Santo (UFES) Ethical Committee and all the procedures followed were in accordance with Resolution 196/96 of Health State Department, Brazil. Forty human maxillary and mandibular molars, extracted with completely formed apices, were obtained from the Human Teeth Bank in the School of Dentistry of the University of São Paulo (FOUSP), São Paulo, Brazil. The teeth were prepared with the aid of eight sets of the rotary nickeltitanium ProTaper ${ }^{\circledR}$ Universal rotary system (Dentsply Maillefer, Ballaigues, Switzerland) that were $25 \mathrm{~mm}$ in length, and were driven by an electric motor with a constant rotation of $350 \mathrm{rpm}$. The following ProTaper ${ }^{\mathbb{B}}$ Universal files were tested: SX, S1, S2, F1, F2, F3, F4 and F5. According to the manufacturer's recommendations, the "crown-down" technique was used. Sixty-four instruments were evaluated in a scanning electron microscope (SEM, Superscan SS-550, Shimadzu, Japan) before and after their use to measure the lengths and the angles of their tips. Observations were made during three different times and grouped as follows: Group A - before the use of the instruments; Group B - after using each instrument in the preparation of three molar teeth, making a total of twenty four molars, and Group C - after using each instrument in the preparation of five molars each, for a total of 16 molar teeth.

All canals were prepared by the same operator who had been previously calibrated. The time taken for the preparation of root canals by each instrument was recorded. The use of a nickel-titanium ProTaper ${ }^{\circledR}$ Universal rotary system kit (Dentsply Maillefer, Ballaigues, Switzerland) (SX, S1, S2, F1, F2, F3, F4 and F5) has been reported to be safe in preventing the fracture of these instruments when used to prepare up to five molar teeth.

The analysis of these surfaces was performed using scanning electron microscopy (SEM, Superscan SS-550, Shimadzu, Japan) by measuring the angles and the lengths of the tips at the Laboratory of Carbonaceous Materials and Ceramic of the Department of Physics, Federal University of Espirito Santo (CCE-UFES), according to Specification No. 101 of ANSI/ADA (12).

All files of the ProTaper ${ }^{\circledR}$ Universal System (Dentsply Maillefer, Ballaigues, Switzerland) were disinfected to remove the surface residues originating from the manufacturing process and instrumentation by brushing with enzymatic detergent, and sterilized in an autoclave in $200 \mathrm{~mL}$ of distilled water in a complete cycle for 30 minutes at $121^{\circ} \mathrm{C}$ and $15 \mathrm{psi}$.

The instruments were attached to the SEM specimen holder with carbon double-sided tape, and the instrument cable slot was positioned upward to standardize the measurements. The long axis of each file was placed parallel to a horizontal reference. To measure the tip length and angle, the image of the tip of the instrument was positioned in the center of the screen at a magnification of $300 \mathrm{X}$ to $400 \mathrm{X}$. The tip length was determined by measuring the length of a straight line drawn parallel to the axis of the instrument, from the apex to the posterior border of the tip, according to ISO 3630-1 (Fig. 1) $(12,13)$. The value was recorded in nanometers $(\mathrm{nm})$ and then converted into millimeters $(\mathrm{mm})$. The posterior limit of the tip of the instrument was delimited by a line perpendicular to the long axis of the instrument, which was tangential to the initial limit of the first helical channel of the active part. The SEM software provided the measurements of the angle enclosed by the two line segments (Fig. 2) (12).

Data analyses included descriptive statistics, Wilcoxon tests for comparison of the length measures, and paired t-test for the comparison of angle measures. The dimensional values were compared with references from the literature and Specification no. $101 \mathrm{ANSI} / \mathrm{ADA}$ (12) at a significance level of $5 \%$. 


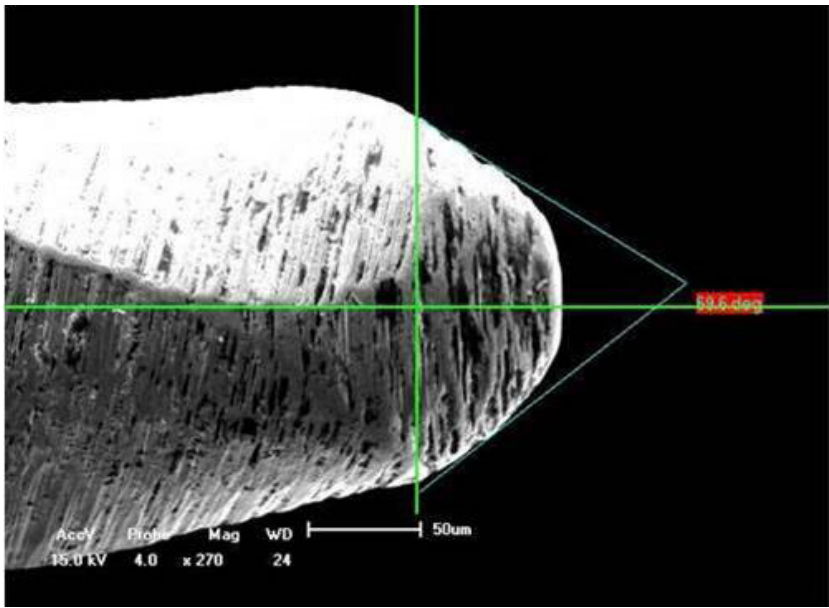

Fig. 1. SEM image of the tip angle geometry of an F2 ProTaper Universal instrument.

\section{Results}

Table 1 shows the descriptive statistical analysis of the angles of the tips measured with the help of the instruments. Table 2 presents the comparisons of tip angle measures between groups (Group A × Group B; Group B $\times$ Group C; Group $\mathrm{A} \times$ Group $\mathrm{C}$ ). There was an increase in the tip angles at all times $(P<0.05)$.

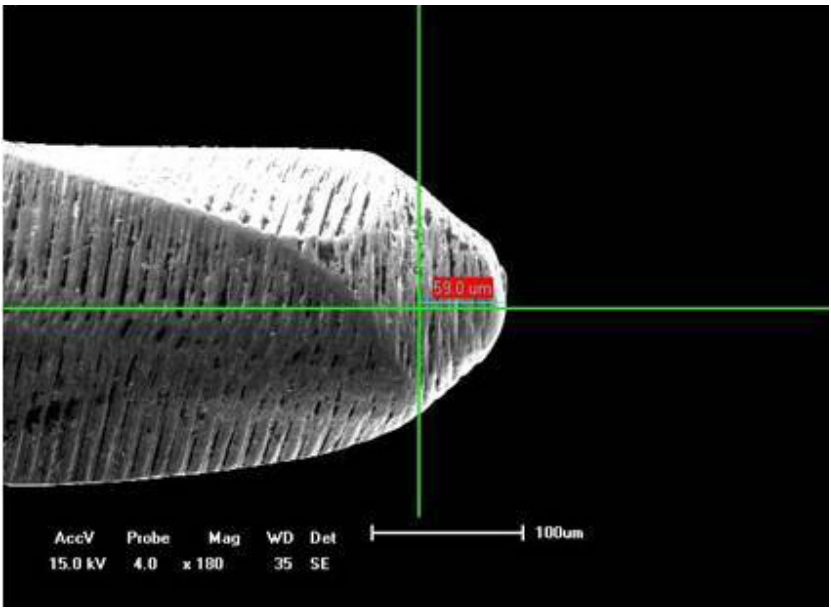

Fig. 2. SEM image of the length of the tip of an F2 ProTaper Universal instrument.

Table 3 shows the descriptive statistical analysis of the lengths of the tips (in mm) measured with the help of the instruments. The data were asymmetric, as shown by differences between the mean and median values. Table 4 shows the results of the Wilcoxon tests for the comparisons of the tip lengths between groups (Group A $\times$ Group B; Group B $\times$ Group C; Group A $\times$ Group C). Some groups showed significant differences in tip angles $(P<0.05)$.
Table 1. Descriptive statistics of the angle (in degrees) of the tips from different experimental groups $(n=8)$.

\begin{tabular}{|c|c|c|c|c|c|c|}
\hline Files & Groups & Minimum & Maximum & Median & Mean & $\begin{array}{l}\text { Standard } \\
\text { deviation }\end{array}$ \\
\hline \multirow{3}{*}{$S X$} & A & 41.000 & 56.000 & 46.000 & 47.125 & 4.853 \\
\hline & B & 42.000 & 57.000 & 48.000 & 48.813 & 4.735 \\
\hline & C & 43.000 & 58.500 & 49.000 & 49.813 & 5.000 \\
\hline \multirow{3}{*}{ S1 } & A & 40.000 & 47.000 & 41.500 & 42.250 & 2.605 \\
\hline & B & 41.000 & 48.000 & 43.500 & 43.813 & 2.419 \\
\hline & C & 42.500 & 49.500 & 44.750 & 45.125 & 2.446 \\
\hline \multirow{3}{*}{ S2 } & A & 42.000 & 50.000 & 45.000 & 45.375 & 3.068 \\
\hline & B & 42.000 & 52.000 & 46.000 & 46.688 & 3.535 \\
\hline & C & 43.000 & 53.000 & 47.250 & 47.938 & 3.438 \\
\hline \multirow{3}{*}{ F1 } & A & 93.000 & 124.000 & 110.000 & 109.750 & 9.377 \\
\hline & B & 95.000 & 125.000 & 112.500 & 111.500 & 9.040 \\
\hline & C & 97.000 & 127.000 & 113.750 & 112.813 & 9.134 \\
\hline \multirow{3}{*}{ F2 } & A & 87.000 & 105.000 & 98.500 & 97.500 & 6.234 \\
\hline & B & 89.000 & 107.000 & 99.500 & 99.250 & 6.065 \\
\hline & C & 90.000 & 109.000 & 101.000 & 100.500 & 6.425 \\
\hline \multirow{3}{*}{ F3 } & A & 51.000 & 97.000 & 84.500 & 79.375 & 14.918 \\
\hline & B & 52.000 & 97.800 & 86.500 & 80.550 & 15.054 \\
\hline & C & 53.500 & 99.000 & 86.750 & 81.688 & 14.856 \\
\hline \multirow{3}{*}{$\mathrm{F} 4$} & A & 100.000 & 109.000 & 103.000 & 103.625 & 2.774 \\
\hline & B & 102.000 & 110.000 & 105.000 & 105.375 & 2.774 \\
\hline & C & 102.500 & 111.000 & 105.750 & 106.500 & 2.752 \\
\hline \multirow{3}{*}{ F5 } & A & 91.000 & 105.000 & 99.000 & 99.000 & 4.870 \\
\hline & B & 92.000 & 105.000 & 99.500 & 99.750 & 4.773 \\
\hline & C & 93.500 & 107.000 & 100.750 & 100.937 & 4.686 \\
\hline
\end{tabular}


Table 2. Results of the paired t-test for comparisons of angle measures between groups.

\begin{tabular}{cccc}
\hline \multirow{2}{*}{ Files } & \multicolumn{3}{c}{ P-value* } \\
\cline { 2 - 4 } & Group A × Group B & Group B $\times$ Group C & Group A × Group C \\
\hline SX & 0.000 & 0.000 & 0.000 \\
S1 & 0.000 & 0.000 & 0.000 \\
S2 & 0.015 & 0.000 & 0.001 \\
F1 & 0.000 & 0.002 & 0.000 \\
F2 & 0.000 & 0.001 & 0.000 \\
F3 & 0.000 & 0.001 & 0.000 \\
F4 & 0.001 & 0.000 & 0.000 \\
F5 & 0.048 & 0.002 & 0.000 \\
\hline
\end{tabular}

* all comparisons are statistically significant at the significance level of 0.05

\begin{tabular}{|c|c|c|c|c|c|c|}
\hline Files & Groups & Minimum & Maximum & Median & Mean & $\begin{array}{l}\text { Standard } \\
\text { deviation }\end{array}$ \\
\hline \multirow{3}{*}{$S X$} & A & 0.060 & 0.107 & 0.087 & 0.086 & 0.015 \\
\hline & B & 0.054 & 0.105 & 0.078 & 0.077 & 0.016 \\
\hline & C & 0.053 & 0.102 & 0.075 & 0.075 & 0.015 \\
\hline \multirow{3}{*}{ S1 } & A & 0.071 & 0.128 & 0.114 & 0.103 & 0.024 \\
\hline & B & 0.064 & 0.119 & 0.107 & 0.098 & 0.023 \\
\hline & C & 0.061 & 0.116 & 0.108 & 0.096 & 0.024 \\
\hline \multirow{3}{*}{$\mathrm{S} 2$} & A & 0.079 & 0.128 & 0.108 & 0.108 & 0.018 \\
\hline & B & 0.069 & 0.120 & 0.097 & 0.094 & 0.019 \\
\hline & C & 0.064 & 0.118 & 0.096 & 0.090 & 0.019 \\
\hline \multirow{3}{*}{$\mathrm{Fl}$} & A & 0.030 & 0.057 & 0.039 & 0.039 & 0.008 \\
\hline & B & 0.027 & 0.052 & 0.030 & 0.033 & 0.009 \\
\hline & C & 0.025 & 0.050 & 0.028 & 0.031 & 0.009 \\
\hline \multirow{3}{*}{ F2 } & A & 0.055 & 0.092 & 0.075 & 0.072 & 0.013 \\
\hline & B & 0.050 & 0.090 & 0.070 & 0.069 & 0.012 \\
\hline & C & 0.048 & 0.087 & 0.066 & 0.066 & 0.012 \\
\hline \multirow{3}{*}{ F3 } & A & 0.060 & 0.120 & 0.079 & 0.085 & 0.022 \\
\hline & B & 0.011 & 0.099 & 0.061 & 0.056 & 0.029 \\
\hline & C & 0.014 & 0.740 & 0.082 & 0.207 & 0.269 \\
\hline \multirow{3}{*}{$\mathrm{F} 4$} & A & 0.063 & 0.080 & 0.069 & 0.070 & 0.006 \\
\hline & B & 0.058 & 0.068 & 0.066 & 0.064 & 0.003 \\
\hline & C & 0.055 & 0.067 & 0.064 & 0.063 & 0.004 \\
\hline \multirow{3}{*}{ F5 } & A & 0.065 & 0.102 & 0.085 & 0.087 & 0.012 \\
\hline & B & 0.060 & 0.092 & 0.079 & 0.079 & 0.011 \\
\hline & C & 0.057 & 0.090 & 0.079 & 0.078 & 0.010 \\
\hline
\end{tabular}

Table 3. Descriptive statistics of the length (in $\mathrm{mm}$ ) of the tips from different experimental groups $(n=8)$.

Table 4. Results of the Wilcoxon test for comparisons of tip length measures between groups.

\begin{tabular}{cccc}
\hline \multirow{2}{*}{ Files } & \multicolumn{3}{c}{ P-value* } \\
\cline { 2 - 4 } & Group A × Group B & Group B $\times$ Group C & Group A × Group C \\
\hline SX & 0.012 & 0.011 & 0.012 \\
S1 & 0.159 & 0.156 & 0.161 \\
S2 & 0.018 & 0.017 & 0.012 \\
F1 & 0.012 & 0.010 & 0.011 \\
F2 & 0.122 & 0.011 & 0.123 \\
F3 & 0.011 & 0.671 & 0.674 \\
F4 & 0.012 & 0.017 & 0.012 \\
F5 & 0.012 & 0.157 & 0.012
\end{tabular}

* P-value in bold is statistically significant at the significance level of 0.05 . 
Table 5. Descriptive statistics of the instrumentation time (in seconds).

\begin{tabular}{cccc}
\hline Files & Median & Mean & Standard deviation \\
\hline Sx & 72.00 & 72.50 & 6.63 \\
S1 & 72.50 & 73.10 & 8.93 \\
S2 & 75.00 & 75.55 & 8.67 \\
F1 & 73.00 & 72.35 & 7.51 \\
F2 & 74.00 & 73.40 & 8.11 \\
F3 & 73.00 & 74.30 & 5.91 \\
F4 & 75.00 & 75.15 & 8.27 \\
F5 & 76.00 & 74.20 & 8.82 \\
\hline
\end{tabular}

Differences were observed among the instruments, Sx, S2, F1 and F4, but there was always a decrease in length. There were no differences between the groups for the S1 instrument. There was a decrease in length between $\mathrm{B}$ and $\mathrm{C}$ groups for the $\mathrm{F} 2$ file and between $\mathrm{A}$ and $\mathrm{B}$ groups for the $\mathrm{F} 3$ file. For the $\mathrm{F} 5$ file, there was a decrease in length from $\mathrm{A}$ to $\mathrm{B}$ groups, but not between $\mathrm{B}$ and $\mathrm{C}$ groups. Table 5 shows the instrumentation time for all groups.

\section{Discussion}

Specific design parameters of the tip, such as the angle, length, cross-section and geometry can significantly influence the clinical efficacy of endodontic instruments (11). The tip angle is formed by the contour of the instrument tip and its vertex. The tip length is the distance between the vertex and the base. The tip angle is related to its length, i.e., the lower the angle of the tip of the file, the greater is its length (14). According to the manufacturer, all ProTaper Universal instruments recently underwent a modification of their tip orientation and geometry.

The results of the present study show that the mean values of the lengths of the tips ranged from 0.075 to $0.108 \mathrm{~mm}$ for Sx, S1 and S2 shaping instruments, and from 0.031 to $0.027 \mathrm{~mm}$ for $\mathrm{F} 1, \mathrm{~F} 2, \mathrm{~F} 3, \mathrm{~F} 4$, and F5 finishing instruments. The comparison of A, B, and C groups reveals a decrease in the tip length for all groups of the shaping ( $\mathrm{Sx}$ and S2) and finishing instruments (F1 and F4).

Miserendino et al. (15) studied the dimensional aspects of seven types of instrument tips as they influence the cutting efficiency. Tip length and angle were two of the dimensional variables analyzed according to Specification \#28 ANSI/ ADA (12). Tips of files with lengths lower than $0.5 \mathrm{~mm}$ and 1.0 to $1.5 \mathrm{~mm}$ had better cutting efficiency. Tip angles with values between $60^{\circ}$ and $69^{\circ}$ showed better performance in atresic root canals than the angles between $40^{\circ}$ and $49^{\circ}$. In root canals with a wider diameter, the tips having smaller angles were the most efficient.
A previous comparison of dimensional and geometric tip changes was reported by Câmara et al. for ProTaper and ProTaper ${ }^{\circledR}$ Universal instruments (17); their mean values for initial tip lengths were greater than the ones reported in the present study. The use of files from different lots in this study may have accounted for some of the confounding effects on the outcome values. The angles of the tips for S1 and S2 ProTaper ${ }^{\mathbb{B}}$ Universal files decreased when compared with the ProTaper system, but they increased for the finishing instruments, F1, F2 and F3. The mean values for the tip lengths ranged from 0.094 to $0.117 \mathrm{~mm}$ for the S1 and S2 shaping files, and from 0.082 to $0.130 \mathrm{~mm}$ for the F1, F2, and F3 finishing files.

Some studies $(11,17)$ reported that specific features such as the design of the tip, tip angle, length, cross-section and tip geometry may significantly affect the penetration, cutting and shaping by endodontic instruments inside the root canal. For ProTaper ${ }^{\circledR}$ Universal instruments, the reduction of the tip angle from $66^{\circ}$ to $39^{\circ}$ is said to favor the centralization of the files inside the root canal walls, thus reducing the risk of transportation. However, in the case of new finishing files, the increase in tip angle from $66^{\circ}$ to $95^{\circ}$ would lead to an opposite effect.

In the present study, the tip angle values in all groups of ProTaper ${ }^{\circledR}$ Universal shaping files ranged from $40^{\circ}$ to $50^{\circ}$, and from $87^{\circ}$ to $124^{\circ}$ in group A of the finishing files. There was an increase in tip angle of all groups of ProTaper ${ }^{\circledR}$ Universal instruments with use, which may provide a safer cutting at the apical third, possibly reducing the risk of fracture and deviation of these files inside the root canal.

\section{Conclusions}

Within the limitations of this study, the results suggest that the tips of rotary instruments showed significant changes in length and angle, even with relatively low use. There was no fracture of shaping and finishing ProTaper ${ }^{\circledR}$ Universal files during this experiment.

\section{Acknowledgments}

The authors acknowledge Dentsply/Maillefer Brazil for the supply of the material, Fundação de Amparo à Pesquisa do Espírito Santo (FAPES), Ministério de Ciências e Tecnologia (MCT), and Financiadora de Estudos e Projetos (FINEP) for the financial support provided for the use of the scanning eletronic microscope. This publication was based on a thesis submitted by the first author to the School of Dentistry, University of Espirito Santo, as a requirement for the MS degree in Dental Clinics (Endodontics). 
1. Kim HC, Yum J, Hur B, Cheung GS. Cyclic fatigue and fracture characteristics of ground and twisted nickel-titanium rotary files. J Endod 2010;36:147-51.

2. Bonetti Filho I, Miranda ER, De Toledo LR, Del Rio CE. Microscopic evaluation of three endodontic files pre- and posinstrumentation. J Endod 1998;24:461-4.

3. Alapati SB, Brantley WA, Svec TA, Powers JM, Mitchell JC. Scanning electron microscope observations of new and used nickel-titanium rotary files. J Endod 2003;29:667-9.

4. Vahid A, Roohi N, Zayeri F. A comparative study of four rotary NiTi instruments in preserving canal curvature, preparation time and change of working length. Aust Endod J 2009;35:93-7.

5. Vaudt J, Bitter K, Kielbassa AM. Evaluation of rotary root canal instruments in vitro: a review. Endod 2007;1:189-203.

6. Bergmans L, Van Cleynenbreugel J, Beullens M, Wevers M, Van Meerbeek B, Lambrechts P. Progressive versus constant tapered shaft design using NiTi rotary instruments. Int Endod J 2003;26:288-95.

7. Inan U, Aydin C, Uzun O, Topuz O, Alcam T. Evaluation of the surface characteristics of used and new ProTaper instruments: an atomic force microscopy study. J Endod 2007;33:1334-7.

8. Ruddle CJ. The ProTaper technique: shaping the future of endodontics. Endod Topics 2005;10:187-90

9. Unal GC, Maden M, Savgat A, Orhan E. Comparative investigation of two rotary nickeltitanium instruments: protaper universal versus protaper. Oral Surg Oral Med Oral Pathol Oral Radiol Endod 2009;107:886-92.

10. Vaudt J, Bitter K, Neumann K, Kielbassa AM. Ex vivo study on root canal instrumentation of two rotary nickel-titanium systems in comparison to stainless steel hand instruments. Int Endod J 2009;42:22-33.

11. West J. Progressive taper technology: rationale and clinical technique for the new ProTaper universal system. Dent Today 2006;25:66-9.

12. American National Standard/American Dental Association. Specification No. 101-2001 [Internet]. Root Canal Instruments: General Requirements. [cited 2010 Jan 20]. Chicago: ANSI/ADA, 2001. Available from: http://webstore.ansi.org/RecordDetail.aspx?sku=ANSI/ ADA+Specification+No.+101-2001.

13. International Organization for Standardization. International Standard ISO 3630-1: 2008 [Internet]. Dentistry - Root-canal instruments. Part 1: general requirements and test methods. [cited 2012 Jun 3]. Geneve: ISO, 2008. Avaliable from: http://webstore.ansi. org/RecordDetail.aspx? sku=ISO+3630-1\%3a2008.

14. Lopes HP, Siqueira Jr JF. Endodontia: biologia e técnica. $3^{a}$ ed. Rio de Janeiro: Guanabara Koogan; 2010.

15. Miserendino LJ. Moser JB, Hever MA, Osetek EM. Cutting efficiency of endodontic instruments. Part II: analysis of tip design. J Endod 1986;12:8-12.

16. American National Standard/American Dental Association. Specification No. 28-2008 [Internet]. Root canal files and reamers, type K; 2008. [cited 2010 Jan 20]. Chicago: ANSI/ADA, 2008. Available from: http://webstore.ansi.org/RecordDetail.aspx? sku=ANS I\%2fADA+Specification +No. +28-2008.

17. Câmara AS, De Castro MR, Viana AC, De Toledo LR, Buono VT, De Azevedo BMG. Flexibility and torsional strength of ProTaper and ProTaper Universal rotary instruments assessed by mechanical tests. J Endod 2009;35:113-6. 